\title{
HISTORIOGRAFI ISLAM INDONESIA: Perspektif Sejarawan Informal
}

\author{
M. Yakub \\ Fakultas Dakwah dan Komunikasi IAIN Sumatera Utara \\ J1. Willem Iskandar Pasar V Medan Estate, 20371 \\ e-mail: yakub.aminn@yahoo.com
}

\begin{abstract}
Abstrak: Artikel ini membahas seputar perdebatan paradigma sejarawan informal di Indonesia dengan corak historiografi yang dihasilkannya. Pendekatan yang dilakukan menggunakan metode historis dengan mereview karya sejarah dalam bentuk tinjauan deskriptif-eksploratif terhadap sejarawan informal yang diwakili oleh Joesoef Sou'yb, HAMKA, dan Ali Hasjmy yang telah menghasilkan karya sejarah umat Islam Nusantara. Penulis menemukan bahwa secara teoritis terdapat tiga kategori sejarawan. Pertama, sejarawan akademik atau profesional yang berasal dari lembaga pendidikan sejarah, dibekali dengan metodologi dan teori-teori ilmiah. Kedua, sejarawan dari disiplin ilmu selain sejarah namun meminati bidang ilmu ini. Ketiga sejarawan dari masyarakat, yaitu sejarawan amatir, seseorang yang tidak bergelar sarjana tetapi lebih produktif menuliskan peristiwa sejarah dibandingkan sejarawan profesional yang karyanya kemudian dikenal dengan historiografi Islam awal di Indonesia.
\end{abstract}

\begin{abstract}
Historiography of Indonesian Islam: An Informal Historian Perspective. This article discusses the debate of informal historian paradigm in Indonesia on historiographical genre produced. This study employs historical method by reviewing historical works with descriptive and explorative approach on informal historians represented by Joesoef Sou'yb, HAMKA, Ali Hasjmy, all of whom have produced historical works of Islamic society in the Indonesian archipelago. The author finds that theoretically, there are three categories of historian, namely, first, academic or professional historians who equipped themselves with history education, scientific theory and methology; second, historians who come from disciples other than history background, but have interest in this field; third, community historians, namely those who do not acquire any academic qualification but nonetheless they are more productive in writing historical events compared to the professional ones, such works of which then to be well known as early Islamic historiography in Indonesia.
\end{abstract}

Kata Kunci: sejarawan informal, historiografi, Islam Indonesia 
MIQOT Vol. XXXVII No. 1 Januari-Juni 2013

\section{Pendahuluan}

Historiografi Islam Indonesia, setidaknya dalam beberapa dasawarsa terakhir, ditandai dengan adanya beberapa perkembangan penting baik secara kuantitatif maupun kualitatif. Menurut Azyumardi Azra, secara kuantitatif munculnya karya-karya sejarah, baik yang ditulis sejarawan Indonesia sendiri maupun sejarawan asing, karya-karya itu dapat dikategorikan sejarah lokal maupun Nusantara, dan global. Karya-karya sejarah ini telah memberikan sumbangan yang signifikan dalam upaya pemahaman yang lebih akurat terhadap sejarah Indonesia secara keseluruhan. ${ }^{1}$ Sementara secara kualitatif, menurut Kuntowijoyo, terlihat dari penggunaan metodologi yang semakin kompleks, yang melibatkan cukup banyak ilmu bantu, khususnya ilmu-ilmu humaniora. ${ }^{2}$

Penggunaan ilmu-ilmu bantu dalam penulisan sejarah Indonesia secara umum dan sejarah Islam Indonesia khususnya, menurut Azra, tidak dapat dimungkiri telah memperkuat dan mengembangkan corak baru dari apa yang disebut kalangan sejarawan Indonesia sebagai "sejarah baru" (new history), sebagai kontras dari "sejarah lama" (old history), yang umumnya bersifat naratif dan deskriptif, atau yang biasa disebut "sejarah ensiklopedis". ${ }^{3}$ Tetapi "sejarah baru" itu sendiri, sebagaimana baru saja diisyaratkan, juga mengalami perkembangan yang cukup signifikan. Pada awal kemunculannya, terutama sejak 1960-an, "sejarah baru" pada umumnya dipahami sebagai alternatif, jika tidak sebagai tandingan "sejarah lama" yang cenderung merupakan "sejarah politik". ${ }^{4}$

Rosenthal, dalam melacak historiografi Islam awal di Indonesia, melihat bahwa bentuk dasar historiografi Islam di Indonesia adalah karya sastra klasik yang isinya banyak menyebutkan istilah-istilah kepada narasi tertentu seperti haba, hikayat, kisah, dan tambo yang berasal dari bahasa Arab. ${ }^{5}$ Argumen ini didukung HAMKA dalam melakukan penulisan Sejarah Umat Islam IV banyak bahannya yang diambil dari historiografi lokal meski bercampur dengan mitos dan legenda, seperti Hikayat Raja-raja Pasai, dan Sejarah Melayu yang menjelaskan interaksi langsung antara Nusantara dengan Arabia. ${ }^{6}$

${ }^{1}$ Azyumardi Azra (ed.), Historiografi Islam Kontemporer: Wacana Aktualitas dan Aktor Sejarah (Jakarta: Gramedia, 2002), h. 3.

${ }^{2} I l m u-i l m u$ humaniora semacam Antropologi dan ilmu-ilmu sosial seperti Sosiologi, ilmu politik, ilmu ekonomi, dan lain-lain. Untuk melihat perkembangan sejarah sosial lihat Kuntowijoyo, Metodologi Sejarah (Yogyakarta: Tiara Wacana Yogya, 2003), h. 39-58.

${ }^{3}$ Azyumardi Azra, "Historiografi Islam Indonesia: Antara Sejarah Sosial, Sejarah Total, dan Sejarah Pinggir," dalam Yudhi Latif (ed.), Menjadi Indonesia: 13 Abad Eksistensi Islam di Bumi Nusantara (Bandung: Mizan, 2006), h. 4.

${ }^{4}$ Ibid.

${ }^{5}$ Salah satu kata yang tersebut di atas adalah Haba yang diambil dari bahasa Aceh yang berarti Khabar dalam bahasa Arab, yang oleh Rosenthal disebutkan sebagai salah satu bentuk dasar Historiografi Islam. Lihat A. Muin Umar, Historiografi Islam (Jakarta: Rajawali Press, 1988), h. 188.

${ }^{6}$ HAMKA, Sejarah Umat Islam IV (Jakarta: Bulan Bintang, 1981). 
Adanya karangan klasik seperti haba, hikayat, kisah, dan tambo inilah yang oleh Rossenthal disebut dapat dijadikan bahan penting dalam studi karya historiografi Islam, sehingga akan terbentuk suatu horizon baru dalam penulisan sejarah Islam yang lebih banyak berpijak pada bumi sendiri dalam pengembangan keahlian dan pengetahuan sejarah Islam yang dilakukan oleh penulis-penulis Islam sendiri. ${ }^{7}$

Menurut Mukti Ali, paling tidak terdapat dua corak pendekatan dalam penulisan sejarah Islam di Indonesia. Pertama, pendekatan sejarah Islam Indonesia sebagai bagian dari sejarah umat Islam. Kedua, pendekatan sejarah Islam Indonesia sebagai bagian dari sejarah nasional Indonesia. ${ }^{8}$ Pendekatan sejarah Islam Indonesia sebagai bagian dari sejarah umat Islam yang diperkenalkan oleh HAMKA dalam bukunya Sejarah Umat Islam IV. ${ }^{9}$

\section{Perdebatan tentang Awal Masuknya Islam ke Indonesia}

Teori HAMKA yang kemudian dikenal dengan teori Arabia, ${ }^{10}$ yakni yang menyebutkan bahwa Islam telah hadir di Nusantara sejak abad ke-7. Teori ini juga didukung oleh Badri Yatim dalam bukunya Sejarah Peradaban Islam. Namun Yatim lebih melihat pada sisi politiknya,

${ }^{7}$ Franz Rosenthal, A History of Muslim (Leiden: E.J. Brill, 1968), h. 8.

${ }^{8}$ Mukti Ali dalam pelaksanaan seminar penulisan sejarah Islam di Indonesia yang diadakan oleh IAIN Sunan Kalijaga Yogyakarta (sekarang UIN Sunan Kalijaga) pada tahun 1985 menjadi seorang pembawa makalah dalam seminar tersebut dan menunjukkan dua buah buku sejarah Islam di Indonesia yang dianggap mewakili pendekatan dalam penulisan sejarah Islam di Indonesia. Dua buku tersebut adalah Sejarah Umat Islam IV karya HAMKA dan Sejarah Nasional Indonesia III karya Uka Tjandrasasmita. Lihat Umar, Historiografi Islam, h. 188.

${ }^{9}$ HAMKA, Sejarah Umat Islam IV.

${ }^{10}$ Setidaknya ada tiga teori yang menjelaskan kedatangan Islam ke Timur Jauh termasuk ke Nusantara. Teori pertama, mengatakan Islam masuk ke Indonesia dari wilayah-wilayah di Anak Benua India. Tempat-tempat seperti Gujarat, Benggali dan Malabar disebut sebagai asal masuknya Islam di Nusantara. Teori ini didukung oleh Snouck Hurgronje dan Pijnappel. Teori kedua, adalah Teori Persia. Tanah Persia disebut-sebut sebagai tempat awal Islam datang di Nusantara. Teori ini berdasarkan kesamaan budaya yang dimiliki oleh beberapa kelompok masyarakat Islam dengan penduduk Persia. Misalnya saja tentang peringatan 10 Muharam yang dijadikan sebagai hari peringatan wafatnya Hasan dan Husein, cucu Rasulullah SAW. Selain itu, di beberapa tempat di Sumatera Barat ada pula tradisi Tabut, yang berarti keranda, juga untuk memperingati Hasan dan Husein. Teori ini menyakini Islam masuk ke wilayah Nusantara pada abad ke-13. Wilayah pertama yang dijamah adalah Samudera Pasai. Teori ketiga, yakni Teori Arabia. Menurut teori ini disebutkan bahwa Islam yang masuk ke Indonesia datang langsung dari Makkah atau Madinah. Waktu kedatangannya pun bukan pada abad ke-12 atau 13, melainkan pada awal abad ke-7. Menurut teori ini, Islam masuk ke Indonesia pada awal abad Hijriyah, bahkan pada masa para khalifah memerintah. Islam sudah mulai ekspedisinya ke Nusantara ketika sahabat Abû Bakar al-Shiddîq, 'Umar bin Khaththâb, Utsmân bin 'Affân dan 'Ali bin Abî Thâlib memegang kendali sebagai Amirul Mukminin. Teori ini didukung oleh sejarawan Indonesia termasuk di dalamnya adalah HAMKA. Lihat HAMKA, Sejarah Umat Islam IV, h. 36-42. Alwi Sihab dalam bukunya Antara Tasawuf Suni \& Tasawuf Falsafi: Akar Tasawuf di Indonesia (Jakarta: Pustaka IIMaN, 2009), h. 6-12. 
dengan artian bahwa perkembangan masyarakat Islam di Indonesia baru terdapat ketika "komunitas Islam" berubah menjadi pusat kekuasaan. ${ }^{11}$

Sementara Taufik Abdullah tidak menyetujui tentang teori yang mengatakan bahwa datangnya Islam pertama kali ke Indonesia pada abad ke- $7 \mathrm{M}$ dengan alasan belum ada bukti bahwa pribumi Indonesia di tempat-tempat yang disinggahi oleh para pedagang Muslim itu beragama Islam. Adanya koloni itu, diduga sejauh yang paling bisa dipertanggungjawabkan, ialah para pedagang Arab tersebut, hanya berdiam untuk menunggu musim yang baik bagi pelayaran. ${ }^{12}$

Pendekatan penulisan sejarah Islam Indonesia yang menekankan pada periode juga dilakukan oleh Yahya Harun. ${ }^{13}$ Ia lebih tertarik terhadap pertumbuhan, perkembangan, dan runtuhnya suatu kerajaan Islam di bumi Nusantara ini. Begitu juga ia lebih menekankan pada peranan pahlawan dan sultan, dan mengkecilkan peranan masyarakat dalam mengembangkan Islam di bumi Nusantara.

Berdasarkan uraian tentang beberapa tulisan sejarah Islam di Indonesia di atas sudah memberi gambaran sekilas tentang adanya karya-karya sejarah Islam yang ditulis oleh penulis-penulis dahulu. Namun tulisan sejarah Islam awal di Indonesia lebih mengarah pada teori dan metode sejarah konvensional yang lebih menonjolkan proses dan tokoh politik serta mengungkapkannya sebagai tulisan deskriptif-naratif, bagaimana peristiwaperistiwa itu terjadi. Juga, memasukkan peristiwa-peristiwa berdasarkan pembabakan besar dalam suatu proses yang linier. Sejarah sebagai suatu narasi besar diperlihatkan melalui peristiwa dan tokoh besar dengan mendokumentasikan asal-usul kejadian, menganalisis genealogi, lalu membangun dan mempertahankan singularitas peristiwa, memilih peristiwa yang dianggap spektakuler (seperti perang), serta mengabaikan peristiwa yang bersifat lokal. ${ }^{14}$

Sementara pendekatan sejarah Islam Indonesia sebagai bagian dari sejarah nasional Indonesia diperkenalkan oleh Uka Tjandrasasmita, seorang arkeolog yang keahliannya khusus mengenai peninggalan-peninggalan Islam di Indonesia. Ia telah mempergunakan sumber sekunder baik berupa buku, artikel dan lain-lainnya, maupun naskah-naskah, hikayat-hikayat daerah dan berita-berita asing yang pernah diterbitkan. Dalam penulisan sejarah Islam Indonesia ia lebih menekankan pada sejarah sebagai proses dalam masyarakat yang terjadi karena pergeseran elemen-elemen yang terdapat dalam masyarakat itu dan kurang memberikan peranan tokoh. ${ }^{15}$

${ }^{11}$ Badri Yatim, Sejarah Peradaban Islam (Jakarta: RajaGrafindo Persada, 2006), h. 191-193.

${ }^{12}$ Abdullah, Taufik dan Moh. Hisyam, (ed.), Sejarah Umat Islam Indonesia (Jakarta: MUI Pusat bekerjasama dengan Yayasan Pustaka Umat, 2003), h. 34. 1995).

${ }^{13}$ Yahya Harun, Islam Nusantara Abad XVI \& XVII (Yogyakarta: Kurnia Kalam Sejahtera

${ }^{14}$ Togi Simanjuntak, Peneliti Sejarah Sosial dan Sejarah Kekerasan pada Institut Riset Sosial dan Ekonomi (Inrise) http://www.duniaesai.com/sejarah/sejarah2.html diakses 01 April 2009.

${ }^{15}$ Uka Tjandrasasmita, Sejarah Nasional Indonesia III (Jakarta: Balai Pustaka, 1977). 
Selain dari Uka Tjandrasasmita, Taufik Abdullah juga menggunakan pendekatan yang sama dalam penulisan sejarah Islam Indonesia. Ia menulis sejarah Islam dalam lingkup sejarah nasional. ${ }^{16}$ Dalam bukunya Sejarah Umat Islam Indonesia, Taufik Abdullah membahas tentang perjuangan umat Islam di Indonesia, yang semula berada dalam konteks politik yang bersifat fragmentaris, untuk membentuk situasi yang integrative-bangsa dan negara Indonesia. Sejarah Islam Indonesia bukan saja merintis proses ke arah integratif nasional, tetapi juga menemukan afinitas dengan nasionalisme Indonesia. ${ }^{17}$

Munculnya pendekatan sejarah Islam Indonesia sebagai bagian dari sejarah nasional Indonesia yang diidentikkan oleh Sartono Kartodirdjo sebagai kumpulan sejarah-sejarah lokal, ${ }^{18}$ secara implisit menggambarkan penulisan baru sejarah Islam Indonesia. Pendekatan semacam itu lebih menekankan pada sejarah sebagai proses dalam masyarakat yang terjadi karena pergeseran elemen-elemen yang terdapat dalam masyarakat itu. ${ }^{19}$

Jika diperhatikan, perkembangan historiografi Islam di Indonesia mengalami perkembangan bersamaan dengan perkembangan historiografi Indonesia itu sendiri. Historiografi Indonesia dimulai dengan munculnya corak historiografi tradisional yang mempunyai unsur-unsur yang tidak bisa lepas dari karya mitologi di mana pihak kerajaan mempunyai peranan penting seperti Empu Prapanca yang menulis kitab Negara Kertagama. ${ }^{20}$

Kemudian pada zaman kolonial, penulisan sejarah didominasi oleh orang-orang Eropa yang datang ke Indonesia. Penulisan sejarah pada masa ini bersifat Eropa-sentris. ${ }^{21}$ Setelah Indonesia merdeka, mulailah penulisan sejarah yang di dominasi oleh para penulis Indonesia yang memperkenalkan historiografi dengan pendekatan Indonesia-sentris. Fokus penulisan sejarah pada masa ini mengangkat tentang tokoh-tokoh pahlawan nasional yang telah berjasa dalam memperjuangkan kemerdekaan dan bahkan banyak biografi tokoh pahlawan nasional yang diterbitkan. ${ }^{22}$

\footnotetext{
${ }^{16}$ Abdullah, Sejarah Umat Islam, h. 17.

${ }^{17}$ Ibid.

${ }^{18}$ Sartono Kartodirdjo, et al., Lembar Sejarah, Beberapa Fasal dari Historiografi Indonesia (Yogyakarta: Yayasan Kanisius, 1968), h. 17.

${ }^{19}$ Pendekatan semacam ini diperkenalkan oleh Uka Tjandrasasmita dalam bukunya Sejarah Nasional Indonesia. Pendekatan penulisan sejarah Islam Indonesia dalam penulisan sejarah nasional juga dilakukan oleh Taufik Abdullah dalam bukunya Sejarah Umat Islam Indonesia.

${ }^{20}$ Pada zaman ini yang menjadi penulis sejarah adalah para pujangga yang bertujuan untuk memuji dan mengkultuskan Raja sebagai pusat kosmik, dan lebih kepada konsep Istanasentris. Lihat Sartono Kartodirdjo, Pemikiran dan Perkembangan Historiografi: Suatu Alternatif (Jakarta: Gramedia, 1982), h. 25.

${ }^{21}$ Pendekatan historiografi semacam ini meletakkan sejarah Indonesia bagian dari sejarah kolonialisme Eropa. Lihat Azra, Historiografi Islam Kontemporer, h. 8.

${ }^{22}$ Menurut Azra penulis paling menonjol dari historiografi Indo-sentris ini adalah Muhammad Yamin yang menulis sejarah Indonesia bahwa Negara Republik Indonesia bukan warisan kolonial akan tetapi mempunyai akar historis yang panjang misalnya Kerajaan Majapahit. Menurut Azra historiografi Indo-sentris ini memunculkan penyalahgunaan sejarah karena sejarah tidak diposisi-
} 


\section{Perspektif Baru Historiografi Islam Indonesia}

Perkembangan baru dalam historiografi Indonesia, dalam pandangan Azra, ditandai dengan munculnya beberapa karya besar sejarah yang melihat sejarah dalam perspektif global. Dalam perspektif sejarah global ini, sejarah Indonesia harus dilihat dan ditempatkan dalam kerangka sejarah dunia pada umumnya. ${ }^{23}$ Salah satu karya sejarah yang menempatkan sejarah pada kerangka global adalah karya Denys Lombard, Nusa Jawa: Silang Budaya, 3 Jilid (aslinya, Le Carrefour Javanais: Essai d'histoire globale, pertama diterbitkan pada 1990). Menurut Azra, karya Denys Lombard dengan judul Nusa Jawa ini telah turut mewakili dan memperkuat momentum bagi kemunculan corak historiografi yang relatif baru bagi kajian-kajian sejarah Indonesia. ${ }^{24}$

Karya lain yang meletakkan kerangka sejarah global adalah mahakarya Anthony Reid, Southeast Asia in the Age of Commerce 1450-1680. Karya ini diterbitkan dalam dua jilid. Jilid pertama, Southeast Asia in the Age of Commerce, Volume One: The Lands below the Winds (1988) dan jilid kedua, Southeast Asia in the Age of Commerce 1450-1680, Volume Two: Expansion and Crisis (1993). ${ }^{25}$

Menurut Azra, kedua karya ini melihat "Nusa Jawa" sesuai istilah Lombard, atau "Negeri Bawah Angin" menurut istilah Reid, dalam perspektif global, persisnya dalam kaitannya dengan perkembangan lingkungan, bahkan dunia di sekitar kedua wilayah tersebut. Perspektif ini secara implisit mengemukakan suatu filosofis sejarah yang menegaskan bahwa perkembangan historis di suatu wilayah tertentu tidaklah terjadi dan berlangsung dalam situasi vakum dan isolatif. Akan tetapi, ia terkait dengan peristiwa-peristiwa pada kawasan lain. Dengan demikian, dalam perspektif ini, sejarah Indonesia harus dilihat dan ditempatkan dalam kerangka sejarah dunia pada umumnya; bukan sejarah yang berdiri sendiri. Hasilnya, pendekatan ini secara implisit berisi pengakuan, bahwa sejarah Indonesia merupakan bagian yang sah dari sejarah dunia secara keseluruhan.

Pendekatan semacam ini, menurut Azra, secara tidak langsung merupakan revisi atas dua pendekatan yang selama ini populer dalam historiografi Indonesia. Pertama, pendekatan yang bersifat eurosentris atau lebih tegas lagi dalam kontek Indonesia Nederlandosentris (berpusat pada Belanda). ${ }^{26}$ Dalam pendekatan ini, sejarah Indonesia dipandang

kan sebagai ilmu melainkan sudah menjadi sebuah ideologi dan tujuan-tujuan tertentu. Lihat Azra, Historiografi Islam Kontemporer, h. 8.

${ }^{23}$ Azra, "Historiografi Islam Indonesia", h. 14.

${ }^{24}$ Ibid, h. 13.

${ }^{25}$ Ibid, h. 7.

${ }^{26}$ Sartono Kartodirjo menamai pendekatan sejarah ini dengan sebutan Eropa-sentris yaitu lebih memandang bangsa Eropa sebagai yang paling baik, dan bangsa di luar tersebut adalah tidak baik. Tetapi dengan berubahnya pandangan menjadi Indonesia-sentris memungkinkan bangsa Indonesia tidak lagi dipandang sebagai bangsa rendahan. Perkembangan yang terlihat pada penulisan sejarah Indonesia adalah kata-kata "pemberontakan" yang dahulu sering ditulis oleh para sejarawan Eropa kini berganti menjadi "perlawanan" atau "perjuangan" hal tersebut 
sebagai bagian dari sejarah kolonialisme Eropa, persisnya ekspansi dan konsolidasi Belanda. Sebagai konsekuensinya, sejarah masyarakat-masyarakat pribumi Indonesia diposisikan tidak pada tempat yang marjinal, tetapi juga dalam perspektif yang peyoratif. ${ }^{27}$

Kedua, pendekatan yang bersifat "indo-sentris", ${ }^{28}$ persisnya yang bertujuan menjadikan Indonesia sebagai sentral atau pusat wacana sejarah. Pendekatan ini sebenarnya berusaha menghindari "ektrimitas" sejarah Euro-sentris. Namun pada gilirannya terjerembab ke kutub ekstrem lainnya. Meski pendekatan Indo-sentris terlihat seolah-olah bertolak belakang dengan pendekatan euro-sentris, namun pandangan dunia yang mendasari keduanya pada dasarnya sama, yakni motif-motif atau kepentingan-kepentingan ideologi tertentu. ${ }^{29}$

Di samping itu, karya Reid atau Lombard juga menggambarkan tentang "sejarah sosial". Walaupun dalam karyanya Lombard memakai istilah "Nusa Jawa" tetapi menurut Azra, pembahasan yang diberikan Lombard lebih dari sekedar tentang "Pulau Jawa" sebagaimana dikenal, tetapi pembahasannya dapat dikatakan mencakup seluruh "Nusantara", dengan Jawa sebagai fokus utamanya. ${ }^{30}$ Begitu juga ketika dilihat dari sub judul karya Lombard berbunyi Essai d'histoire globale yang menurut Azra, secara harfiah seharusnya diterjemahkan sebagai "Esai Sejarah Total". ${ }^{31}$ Secara implisit menjelaskan corak penulisan sejarah yang dianut oleh Lambard yakni sejarah global atau, lebih populer lagi, "sejarah total" (total history), yang sering juga disebut disebut sebagai "New History". ${ }^{32}$

Dengan sub judul ini mengisyaratkan bahwa Lombard ingin menulis sejarah Jawa secara global atau tepatnya, secara total dan ini dengan segera menjelaskan akar-akar historiografi yang mendasari pandangan dunia seorang Lombard. Dengan pendekatan sejarah total, Lombard dengan leluasa membahas berbagai aspek kehidupan masyarakat

logis karena sebagai bangsa yang terjajah tentu saja harus melawan untuk mendapatkan kemerdekaan dan kebebasan. Kartodirdjo, Pemikiran dan Perkembangan Historiografi Indonesia, h. 19-22.

${ }^{27}$ Azra, "Historiografi Islam Indonesia", h. 14.

${ }^{28}$ Indo-sentris yang artinya penulisan sejarah yang mengutamakan atau mempunyai sudut pandang dari Indonesia sendiri. Pada masa sebelumnya yaitu masa kolonial, penulisan sejarah sangat Eropa sentris karena yang melakukan penulisan tersebut adalah orang-orang Eropa yang mempunyai sudut pandang bahwa orang Eropa merupakan yang paling baik. Penulisan sejarah yang Indonesia sentris memang sudah dimulai jauh pada masa kerajaankerajaan, tetapi kemudian ketika bangsa Barat masuk ke Indonesia maka era penulisan sejarah yang Indonesia sentris mulai meredup dan digantikan oleh historiografi yang Eropa sentris. Lihat Kartodirjo, Pemikiran dan Perkembangan Histriografi Indonesia, h. 22-23.

${ }^{29}$ Azra, "Historiografi Islam Indonesia", h. 15.

${ }^{30}$ Azra, Historiografi Islam Kontemporer, h. 11.

${ }^{31}$ Azra kurang sepakat dengan terjemahan bahasa Indonesia sub judul Essai d'histoire globale dengan "Kajian Sejarah Terpadu". Menurut Azra sub judul tersebut seharusnya diterjemahkan secara harfiah "Esai Sejarah Total" karena hal itu akan menggambarkan corak penulisan sejarah yang dianut oleh Lombard.

${ }^{32}$ Arthur Marwick, The Nature of History (London: Mcmillan Education, 1985), h. 64. 
dalam perkembangan historisnya, sejak dari geografi, pelapisan sosial, demografi, estetika, ekonomi dan perdagangan, birokrasi, dan peranan wanita.

Dari paparan kedua karya tersebut telah memberi gambaran tentang perkembangan historiografi Indonesia. Harus diakui bahwa kedua karya tersebut di atas telah memengaruhi corak historiografi Indonesia sehingga historiografi Indonesia semakin cenderung bersifat global dan total.

Perkembangan historiografi Indonesia ini diakui oleh Azra juga berdampak pada perkembangan historiografi Islam Indonesia. Dalam kurun waktu terakhir ini, sejarah Islam di Indonesia tidak lagi dilihat dari perspektif lokal, sebagaimana selama ini cenderung dilakukan para sejarawan, tetapi dalam perspektif global dan total, yang melihat sejarah Islam di Indonesia dalam kaitannya dengan perkembangan historis Islam di kawasankawasan lain. ${ }^{33}$

Salah satu karya penting tentang sejarah Islam Indonesia yang menempatkan sejarah pada kerangka total atau global adalah karya Azyumardi Azra, Jaringan Ulama Timur Tengah dan Kepulauan Nusantara Abad XVII dan XVIII. ${ }^{34}$ Dalam karyanya ini, Azra melakukan penelitian terhadap ulama Nusantara, khususnya pada pada abad 17 dan 18 dalam kaitan dengan wacana intelektual keagamaan (religio-intellectual discourse) ulama Indonesia di Makkah dan Madinah (Haramain) dan sekaligus tentang hubungan dinamika Islam di Nusantara dengan perkembangan Islam di kawasan dunia Muslim lainnya.

Penelitian Azra tentang wacana intelektual keagamaan (religio-intellectual discourse) ulama Indonesia di Makkah dan Madinah (Haramayn) mencoba melacak sejarah sosialintelektual ulama Nusantara dalam kaitannya dengan Dunia Islam yang lebih luas. Menurut Azra wacana intelektual keagamaan ini berpusat pada semacam jaringan ulama (networks of the ulama) yang berpusat di Makkah dan Madinah (Haramain). ${ }^{35}$

Kajian sejarah sosio-intelektual ulama Nusantara yang telah dilakukan Azra ini merupakan hal yang baru, sebab pada umumnya pengkajian tentang ulama-ulama Indonesia berbentuk pengkajian biografis, yang terlalu memusatkan pada ulama bersangkutan, sehingga cenderung terlepas dalam konteks sosio-intelektual yang mengitari mereka. Sementara itu, terdapat pula beberapa studi yang lebih memusatkan perhatian pada peran keagamaan dan politik yang mereka mainkan dalam kurun waktu tertentu sejarah Nusantara. ${ }^{36}$

Karya penting lainnya dari Azra yang perlu disebut dalam tarikan nafas yang sama

\footnotetext{
${ }^{33}$ Penilaian ini diberikan oleh sejarawan Islam Indonesia seperti Azra. Lihat dalam bukunya Historiografi Islam Kontemporer, h. 9.

${ }^{34}$ Azyumardi Azra, Jaringan Ulama Timur Tengah dan Kepulauan Nusantara Abad XVII dan XVIII (Bandung: Mizan, 1994).

${ }^{35}$ Ibid.

${ }^{36} \mathrm{Ibid}$, h. 15.
} 
adalah Islam Nusantara: Jaringan Global dan Lokal. ${ }^{37}$ Buku ini merupakan historical account tentang Islam di Nusantara dengan menggunakan pendekatan multidisipliner-ilmu sejarah yang dipadu dengan ilmu-ilmu lain, seperti antropologi, sosiologi, ilmu politik, dan perbandingan agama. Karya Azra ini juga menegaskan bahwa perkembangan historis di suatu wilayah tertentu tidaklah terjadi dan berlangsung dalam situasi vakum dan isolatif. Tetapi ia terkait dengan peristiwa-peristiwa pada kawasan lain. Karena itu, Azra melihat bahwa dinamika Islam Nusantara tidak pernah lepas dari dinamika dan perkembangan di kawasan-kawasan lain, wilayah yang kini disebut sebagai Timur Tengah. Kerangka, koneksi, dan dinamika global itu dapat dipastikan membentuk atau setidak-tidaknya memengaruhi dinamika dan tradisi lokal di Nusantara. ${ }^{38}$

Kedua karya Azra ini secara implisit telah menjelaskan tentang corak penulisan sejarah yang dianutnya yakni sejarah global atau, lebih populer lagi, "Sejarah Total" (total history). Sejarah Islam di Indonesia, dalam pandangan Azra, harus dilihat dalam perspektif global dan total, yakni melihat sejarah Islam di Indonesia dalam kaitan dengan perkembangan historis Islam di kawasan-kawasan lain. Dengan studinya ini, Azra berargumen bahwa perjalanan historis Islam di Indonesia sepanjang sejarah tidak dapat dilepaskan dari perkembangan Islam di Arabia dan kawasan-kawasan Muslim lainnya. ${ }^{39}$

Karya sejarah lainnya yang sama dengan corak penulisan sejarah Azra adalah kajian yang dilakukan oleh Abaza tentang mahasiswa Indonesia di Kairo. Kajian Abaza dapat disebut sebagai "sejarah kontemporer" mahasiswa Indonesia yang menuntut ilmu di Kairo dan peranan mereka setelah kembali ke Indonesia. Kajian Abaza ini menekankan tentang proses cultural exchange, atau yang disebut Azra sebagai transmission of Islamic Learning. ${ }^{40}$

Sementara karya lainnya adalah kajian yang dilakukan oleh Von der Mehden tentang interaksi dan hubungan antara Islam di Asia Tenggara dan Islam di Timur Tengah. Karya ini berusaha mengungkapkan dinamika interaksi di antara kedua wilayah Muslim ini dalam berbagai aspek kehidupan, seperti politik, ekonomi, dan intelektual. ${ }^{41}$ Meski cukup berhasil dalam mengungkapkan dampak interaksi dan hubungan di antara wilayah ini dalam perkembangan Islam di Asia Tenggara, namun menurut Azra dalam segi-segi tertentu kajian ini memiliki kelemahan dan kekurangan yang cukup menyolok. ${ }^{42}$

${ }^{37}$ Azyumardi Azra, Islam Nusantara: Jaringan Global dan Lokal (Bandung: Mizan, 2002), h. 7.

${ }^{38}$ Ibid.

${ }^{39}$ Pendekatan historiografi Islam modern yang mengarah pada perspektif modern ini seperti yang ditulis oleh Azra yang menulis tentang perkembangan Islam di Indonesia pada abad ke 17 dan 18 dalam kaitannya dengan kebangkitan jaringan ulama di Makkah dan Madinah, serta banyak bagian dunia Muslim lainnya. Lihat Azra, Jaringan Ulama Timur Tengah.

${ }^{40}$ Mona Abaza, Islamic Education, Perception and Exchanges: Indonesia Students in Cairo (Paris: Caheir d'Archipel No.33, 1993). Lihat juga Azra, Historiografi Islam Kontemporer, h. 4.

${ }^{41}$ Fred R. Von der Mehden, Two Worlds of Islam: Introduction Between Southeast Asia and Middle East (Gainsville: University Press of Florida, 1993).

${ }^{42}$ Azra, Historiografi Islam Kontemporer, h. 4. 
Sementara corak historiografi awal Islam di Indonesia adalah historiografi yang mendekati sejarah Islam di Indonesia sebagai bagian dari sejarah umat Islam. Dalam hal ini, penekanan historiografi lebih ditekankan kepada periode dan memberikan penekanan kepada peranan pahlawan dan sultan dalam bangun dan tenggelamnya Kerajaan Islam di Kepulauan Nusantara.

Pada perkembangan selanjutnya, muncul pendekatan sejarah Islam sebagai bagian dari sejarah nasional Indonesia. Jadi, historiografi Islam di Indonesia pada masa ini dianggap sebagai bagian dari sejarah nasional Indonesia yang penekanannya pada sejarah sebagai proses dalam masyarakat yang terjadi karena pergeseran elemen-elemen yang terdapat dalam masyarakat itu.

Kemudian sejak 1960-an, muncul penulisan sejarah Islam Indonesia yang sering disebut kalangan sejarawan Indonesia sebagai "sejarah baru" (new history) yang cenderung dipahami sebagai "sejarah sosial" (social history) yakni sejarah yang lebih menekankan kepada kajian dan analisis terhadap faktor-faktor bahkan ranah-ranah sosial yang mempengaruhi terjadinya peristiwa-peristiwa sejarah itu sendiri. Dalam sejarah baru ini, historiografi Islam Indonesia tidak lagi dilihat dari perspektif lokal, sebagaimana selama ini cenderung dilakukan oleh para sejarawan, tetapi dalam perspektif global dan total, yang melihat sejarah Islam di Indonesia dalam kaitan dengan perkembangan historis Islam di kawasan-kawasan lain.

\section{Historiografi Sejarawan Informal}

Historiografi Islam di Indonesia pada mulanya tidak menampakan ciri yang jelas sebagai sejarah Islam, namun hanya berbentuk karya sastra klasik. Kemudian sejarah Indonesia dibangun atas dua pendekatan yakni sejarah Islam Indonesia sebagai bagian dari sejarah umat Islam dan sejarah Islam Indonesia sebagai bagian dari sejarah Nasional Indonesia. ${ }^{43}$

Sementara corak historiografi awal Islam di Indonesia adalah historiografi yang mendekati sejarah Islam di Indonesia sebagai bagian dari sejarah umat Islam. Dalam hal ini, penekanan historiografi lebih ditekankan kepada periode dan memberikan penekanan kepada peranan pahlawan dan sultan dalam bangun dan tenggelamnya kerajaan Islam di Kepulauan Nusantara.

\footnotetext{
${ }^{43}$ Pembagian ini disampaikan oleh Mukti Ali dalam pelaksanaan seminar penulisan sejarah Islam di Indonesia yang diadakan oleh IAIN Sunan Kalijaga Yogjakarta pada tahun 1985 menjadi seorang pembawa makalah dalam seminar tersebut dan menunjukkan dua buah buku sejarah Islam di Indonesia yang dianggap mewakili pendekatan dalam penulisan sejarah Islam di Indonesia. Dua buku tersebut adalah Sejarah Umat Islam IV karya HAMKA dan Sejarah Nasional Indonesia III karya Uka Tjandrasasmita. Lihat A. Muin Umar, Historiografi Islam (Jakarta: Rajawali Press, 1988), h. 188.
} 
Munculnya bermacam-macam bentuk sejarah Islam Indonesia, tentunya berbanding lurus dengan profesi penulis sejarah itu sendiri. Kuntowijiyo melihat bahwa sejarawan itu ada tiga golongan menurut pendidikannya (1) sejarawan profesional, (2) sejarawan dari disiplin lain, (3) sejarawan dari masyarakat. ${ }^{44}$ Sementara Azra memetakan sejarawan menjadi dua yaitu sejarawan profesional (historian by profession) atau sejarawan akademik (academic historian) dan sejarawan informal (informal historian). ${ }^{45}$

Menurut Kuntowijoyo, sejarawan profesional adalah sejarawan yang berasal dari lulusan lembaga pendidikan sejarah. Ia dibekali dengan bekal metodologi dan teori-teori ilmiah bidang ilmu sejarah. ${ }^{46}$ Sejarawan dari disiplin lain adalah sejarawan yang bukan lulusan pendidikan sejarah. Ia dapat berasal dari lulusan bidang hukum, eksakta, atau agama, namun meminati bidang sejarah, dan sejarawan dari masyarakat adalah "sejarawan amatir", ia tidak bergelar sarjana tetapi belum tentu buruk menulis sejarah. ${ }^{47}$

Berbeda dengan Kuntowijoyo, Azra mengutip pendapat Carl Becker dengan memberi persamaan antara sejarawan akademik (academic historian) dengan "sejarah tinggi" dan sejarawan informal (informal historian) dengan "sejarah rendah". ${ }^{48}$ Menurut Azra sejarah tinggi adalah sejarah yang menghendaki berbagai kemampuan sejarawan dan peneliti sejarah untuk mengungkapkan dan menjelaskannya kepada publik. Sementara pengertian "sejarah rendah" memberikan pengertian sejarah secara sangat atau paling longgar. ${ }^{49}$

Dalam pandangan Azra selanjutnya, bahwa yang dikatakan sebagai sejarawan akademik atau sejarawan profesional (historian by profession) adalah orang yang mampu membaca perkembangan-perkembangan dalam ilmu sejarah yang tidak hanya menguasai teori dan metode sejarah saja, tetapi juga bidang-bidang keilmuan lain. Sejarawan dan peneliti sejarah tidak cukup lega hanya menghabiskan waktu meneliti arsip, dokumen, dan sumbersumber sejarah lain, mereka harus pula menggulati sumber-sumber lain di luar bidang sejarah. $^{50}$

Dengan demikian, sejarawan akademis kelihatan menjadi semakin sulit karena dalam melakukan penelitian sejarah harus melintasi batas-batas sempit yang membatasi paradigma keilmuan sejarah untuk kemudian juga mengetahui ilmu-ilmu lain seperti antropologi, sosiologi, ilmu politik, dan psikologi. Karena itulah, sejarah sekarang menjadi semakin antropologis (anthropological history), atau lebih sosiologis (sociological history),

${ }^{44}$ Kuntowijoyo, Metodologi Sejarah (Yogyakarta: Tiara Wacana, 2003), h. 83-85.

${ }^{45}$ Azra, Historiografi Islam Kontemporer, h. 83.

${ }^{46}$ Kuntowijoyo, Metodologi Sejarah, h. 84. Yang dapat dikategorikan ke dalam sejarawan profesional adalah Sartono Kartodirjo, Kuntowijoyo, Taufik Abdullah, Abdurrahman Surjomiharjo, dan Azyumardi Azra. Kelimanya murni alumni lembaga pendidikan sejarah.

${ }^{47}$ Menurut Kuntowijoyo, para kiai, lurah, dan santri juga dapat menulis sejarah, misalnya sejarah pondoknya sendiri. Lihat Kuntowijoyo, Metodologi Sejarah, h. 85-86.

${ }^{48}$ Azra, Historiografi Islam Kontemporer, h. 83.

${ }^{49}$ Ibid, h. 85.

${ }^{50} \mathrm{Ibid}$, h. 83. 
atau lebih psikologis (psychological history), dan seterusnya. Jika tidak, sejarawan atau peneliti sejarah akan gagal menjelaskan sejarah dengan cara yang menyakinkan dan mampu memberikan pencerahan kepada masyarakat. Sebaliknya, ilmu-ilmu lain juga semakin historis. Sebab itulah berkembang misalnya, antropologi historis (historical antropology), dan sosiologi historis (historical sociology).

Sementara sejarawan informal (informal historian) atau sejarah rendah, Azra mengutip pendapat Becker, yang memberikan pengertian sejarah secara sangat atau paling longgar. Becker mengatakan "history is the memory of things said and done". Dalam pengertian ini bahkan "sejarah sebagai kenangan tentang hal-hal yang dikatakan dan diperbuat (seseorang) tidak lagi menggunakan keterangan waktu" di "masa silam". Karena jika definisi sejarah sebagai "kenangan tentang hal-hal yang dikatakan dan dilakukan" ditambahi dengan "di masa silam", maka tidak bisa dielakkan konotasinya adalah "masa silam yang jauh" (distance past). ${ }^{51}$

Sementara dalam pandangan Ibrahim Alfian, sejarah itu dapat ditulis oleh siapa saja tanpa harus melalui jenjang akademik ilmu sejarah. Menurutnya, rekonstruksi masa lampau tidak hanya dilakukan oleh para sejarawan akademik yang mendapat pendidikan formal dalam ilmu sejarah dengan hasil yang idealnya deskriptif analitik, tetapi juga oleh para sejarawan amatir pada umumnya.

Pendapat Ibrahim Alfian ini juga didukung oleh Kuntowijoyo yang mengatakan, banyak penulis sejarah yang dikira "amatir", ternyata menghasilkan karya karya bermutu. Kuntowijoyo memberi contoh bahwa Rusli Amran telah menulis sekitar Plakat Panjang di Sumatera Barat dengan penelitian yang lebih dari seseorang terdidik. Demikian juga Luckman Sinar yang sehari-harinya adalah pengusaha yang sibuk, tetapi masih sempat menulis sejarah dengan baik. ${ }^{52}$

\section{Metode dan Sistem Penulisan Sejarawan Informal}

Pada prinsipnya, para sejarawan akademik diharuskan berpegang teguh dengan kaedah-kaedah penulisan sejarah secara ketat, rinci dan valid. Ciri ilmiah menjadi hal pokok dalam menuliskan hasil penelitian sejarah antara lain memiliki tujuan dan objek tertentu baik (objek material maupun objek formal). Penggunaan metode yang konsisten dalam arti diterapkan dalam keseluruhan uraian secara terpadu dan saling terkait. Bersifat sistematis, artinya uraian tidak saling bertentangan melainkan runtut dan saling mengikat antara satu objek dengan objek lainnya. Bersifat empiris, yaitu hasil karya sejarah sesungguhnya merupakan rekonstruksi kejadian masa lalu yang diperoleh melalui pengalaman dan observasi (empirical fact). Ciri pokok lainnya adalah bersifat rasional, objektif, dan dapat diverifikasi.

${ }^{51} \mathrm{Ibid}$, h. 85.

${ }^{52}$ Kuntowijoyo, Metodologi Sejarah, h. 86. 
Tidak demikian halnya dengan sejarawan informal yang menuliskan karya sejarah tanpa dibekali pendidikan akademik dalam bidang sejarah secara mendalam. Namun, sebagaimana pengakuan sejarawan akademik, seperti Azyumardi Azra, Ibrahim Alfian, dan Kuntowijoyo, mereka mengapresiasi dengan baik apa yang dihasilkan oleh para sejarawan informal. Karena paling tidak telah memenuhi kriteria minimal karakteristik dan fungsinya dalam penulisan sejarah.

Kriteria yang dimaksud yaitu: Pertama, tema, yaitu perumusan pokok terhadap suatu objek yang akan dibahas apakah politik, ideologi, adat istiadat, dan tradisi budaya. Kedua, sumber data, yaitu rujukan seorang penulis ketika melakukan eksplorasi karya-karya yang dihasilkannnya baik sumber primer maupun sumber sekunder. Ketiga, metodologi dan pendekatan, yaitu susatu cara atau jalan untuk bertindak menuntun peneliti dengan seperangkat aturan tertentu sehingga dapat melakukan aktivitas penelitian dengan lebih terarah. Keempat, konsep dan model, yaitu suatu abstraksi mengenai suatu gejala atau realitas. ${ }^{53}$ Sedangkan proses penentuan konsep disebut konseptualisasi, yaitu aktifitas membagi dan memilah serta mengelompokkan atas dasar persamaan dan perbedaan tentang suatu objek yang diteliti. Dari penentuan konsep tersebut, maka akan melahirkan model tertentu seperti model penelitian empiris, heuristik, fenomenologi atau metafisik. Kelima, persprektif, ${ }^{54}$ yaitu cara seorang sejarawan atau peneliti mengamati dan membingkai masalah yang sedang diteliti. Tidak dapat disangkal bahwa suatu objek yang diteliti terdiri atas berbagai aspek, akan tetapi tidak semua aspek dalam satu objek dapat dilihat secara keseluruhan. Sebab itu, diperlukan perspektif tertentu dalam melihatnya. Objek yang sama dapat memiliki hasil yang berbeda sesuai dengan perspektif yang digunakan untuk melihatnya.

Sejauh penelitian dan analisis yang dilakukan terhadap karya-karya yang dihasilkan oleh tiga sejarawan informal, dalam artikel ini, karya-karya tersebut telah memenuhi kelima langkah di atas yang dapat diterima sebagai metode dan sistem penulisan sejarawan informal, khususnya di Indonesia. ${ }^{55}$ Banyak dari mereka yang menghasilkan karya kesejarahan dan telah memberikan kontribusi kepada aspek-aspek tertentu pengetahuan tentang sejarah manusia dan bangsa Indonesia. Tidak diragukan lagi bahwa ini telah membantu untuk memahami sejarah secara lebih baik. ${ }^{56}$

\section{h. 28 .}

${ }^{53}$ Dudung Abdurahman, Metode Penelitian Sejarah (Jakarta: Logos Wacana Ilmu, 1999),

${ }^{54}$ Rustam E. Tamburaka, Pengantar Ilmu Sejarah, Teori Filsafat Sejarah, Sejarah Filsafat \& Iptek (Jakarta: Rineka Cipta, 1999), h. 17.

${ }^{55}$ Tokoh seperti Rosihan Anwar, Ramadhan KH, HAMKA, dan Joesoef Sou'yb adalah beberapa tokoh sejarawan informal yang hasil karya sejarahnya sampai sekarang masih menjadi rujukan bagi pemburu sejarah. Bahkan Rosihan Anwar dan Ramadhan KH mendapatkan anggota kehormatan pada Kongres Nasional Sejarah VII dan Kongres Masyarakat Sejarawan Indonesia (MSI) $\mathrm{V}$ karena mereka telah memberikan banyak kontribusi tentang sejarah manusia dan bangsa Indonesia melalui karya sejarah mereka.

${ }^{56}$ Azra, Historiografi Islam Kontemporer, h. 83-84. 
Ada beberapa nama sejarawan informal yang telah menghasilkan karya sejarah monumental, misalnya HAMKA. ${ }^{57}$ Ia adalah seorang otodidak dalam berbagai bidang ilmu pengetahuan seperti filsafat, sastra, sejarah, sosiologi dan politik, baik Islam maupun Barat. Ia juga termasuk seorang ulama, aktivis politik dan penulis yang produktif di antaranya adalah tentang Sejarah Umat Islam. ${ }^{58}$

Selain HAMKA, A. Hasjmy asal Aceh juga merupakan sejarawan informal yang karyakarya sejarahnya juga telah memberikan banyak kontribusi kepada aspek-aspek tertentu pengetahuan kita tentang sejarah manusia dan bangsa kita. Tidak ragu lagi telah membantu kita memahami sejarah kita secara lebih baik.

Mukti Ali mengatakan, paling tidak terdapat dua corak pendekatan dalam penulisan sejarah Islam di Indonesia. Pertama. Pendekatan sejarah Islam Indonesia sebagai bagian dari sejarah umat Islam. Pendekatan historiografi ini lebih ditekankan kepada periode dan memberikan penekanan kepada peranan pahlawan dan sultan dalam bangun dan tenggelamnya kerajaan Islam di Kepulauan Nusantara. Kedua. Pendekatan sejarah Islam Indonesia sebagai bagian dari sejarah nasional Indonesia. ${ }^{59}$ Historiografi Islam di Indonesia pada masa ini dianggap sebagai bagian dari sejarah nasional Indonesia yang penekanannya pada sejarah sebagai proses dalam masyarakat yang terjadi karena pergeseran elemenelemen yang terdapat dalam masyarakat itu.

Kalau dilihat karya HAMKA, Sejarah Umat Islam IV, dalam histogriografinya, ia menggunakan pendekatan sejarah Islam Indonesia sebagai bagian dari sejarah umat Islam. ${ }^{60}$ Karena dalam buku ini pengelompokannya lebih banyak ditekankan kepada periode daripada daerah. Penekanannya lebih banyak kepada peranan pahlawan dan sultan dalam bangun tenggelamnya kerajaan Islam di kepulauan Nusantara, sehingga dengan demikian heroworship nampaknya dipegang oleh HAMKA dalam penulisan sejarah Islam.

Dalam bukunya Sejarah Masuk dan Berkembangnya Islam di Indonesia, A. Hasjmi

${ }^{57}$ HAMKA (1908-1981) adalah akronim nama dari Haji Abdul Malik bin Abdul Karim Amrullah. Ia adalah seorang ulama, aktivis politik dan penulis Indonesia yang amat terkenal di alam Nusantara. Beliau lahir pada 17 Februari 1908 di Kampung Molek, Maninjau, Sumatera Barat, Indonesia. Ayahnya ialah Syaikh Abdul Karim bin Amrullah atau dikenali sebagai Haji Rasul, seorang pelopor gerakan pembaharuan di Minangkabau, sekembalinya dari Makkah pada tahun 1906.

${ }^{58}$ Beberapa karya sejarah HAMKA yakni Sejarah Ummat Islam Jilid 1, ditulis selama masa 1938 sampai 1950. Sejarah Ummat Islam Jilid 2, Sejarah Ummat Islam Jilid 3, dan Sejarah Ummat Islam Jilid 4.

${ }^{59}$ Mukti Ali dalam pelaksanaan seminar penulisan sejarah Islam di Indonesia yang diadakan oleh IAIN Sunan Kalijaga Yogyakarta pada tahun 1985 menjadi seorang pembawa makalah dalam seminar tersebut dan menunjukkan dua buah buku sejarah Islam di Indonesia yang dianggap mewakili pendekatan dalam penulisan sejarah Islam di Indonesia. Dua buku tersebut adalah Sejarah Umat Islam IV karya HAMKA dan Sejarah Nasional Indonesia III karya Uka Tjandrasasmita. Lihat Umar, Historiografi Islam, h. 188.

${ }^{60}$ Umar, Historiografi Islam, h. 188. 
menggunakan pendekatan sejarah Islam Indonesia sebagai bagian dari sejarah umat Islam. Dalam bukunya tersebut ia lebih menekankan kepada periode daripada daerah. Begitu juga peranan pahlawan dan sultan sangat dominan dalam bangun dan tenggelamnya kerajaan Islam di kepulauan nusantara. ${ }^{61}$

Pendekatan semacam inilah, HAMKA, kemudian melakukan revisi tentang sejarah pertama kali masuknya Islam ke Indonesia, yang kemudian dikenal dengan teori Arabia sebagaimana telah dijelaskan di atas. Menurut HAMKA, Islam masuk ke Indonesia datang langsung dari Makkah atau Madinah. Waktu kedatangannya pun bukan pada abad ke12 atau 13, melainkan pada awal abad ke-7. Artinya, Islam masuk ke Indonesia pada awal abad Hijriyah, bahkan pada masa para khalifah memerintah. Islam sudah mulai ekspidesinya ke Nusantara ketika sahabat Abû Bakar al-Shiddîq, 'Umar bin Khaththâb, Utsmân bin 'Affân dan Ali bin Abî Thâlib memegang kendali sebagai Amirul Mukminin. ${ }^{62}$

HAMKA menolak pandangan yang menyatakan bahwa agama Islam masuk ke Indonesia pada abad ke-13 dan berasal dari Gujarat. HAMKA lebih mendasarkan teorinya pada peranan bangsa Arab dalam penyebaran Islam di Indonesia. Gujarat hanyalah merupakan tempat singgah, dan Makkah adalah pusat Islam, sedang Mesir sebagai tempat pengambilan ajaran. HAMKA menekankan pengamatannya kepada masalah Mazhab Syâfi'î yang istimewa di Makkah dan mempunyai pengaruh besar di Indonesia.

Senada dengan HAMKA, A. Hasjmy juga mempunyai pandangan yang sama kedatangan Islam di Indonesia bukan pada abad ke-12 atau 13, melainkan abad ke-7. Hal ini didasarkan pada naskah Idhar al- $\underline{H} a q q f i$ Mamlakat Ferlah wal Fâsi, karangan Abû Ishaq al-Makarani al-Fâsi, Tazkirat Tabâqât Jumu Sulthanu al- Salâtin karya Syaikh Syamsul Bahri Abdullah, al-Asyi, dan Silsilah Raja-raja Perlak dan Pasai. A. Hasjmy menyatakan bahwa Kerajaan Perlak (Aceh) adalah Kerajaan Islam pertama di Nusantara yang didirikan pada tanggal 1 Muharam 225 H (840 M) dengan raja pertamanya Sulthan Alaudin Sayyid Maulana 'Abdil 'Aziz Syah. Teori ini kemudian banyak didukung oleh cendikiawan Nusantara dan dimasukkan dalam buku teks pengajaran Perguruan Tinggi. ${ }^{63}$

Teori Arabia ini diperkuat dengan bukti catatan-catatan resmi dan jurnal Cina pada periode dini Dinasti Tang ${ }^{64} 618$ M yang secara ekplisit menegaskan bahwa Islam sudah masuk wilayah Timur jauh, yakni Cina dan sekitarnya ${ }^{65}$ pada abad pertama Hijriyah melalui lintas laut dari bagian Barat Islam. Cina yang dimaksudkan pada abad pertama Hijriyah

\footnotetext{
${ }^{61}$ A. Hasjmy (ed.), Sejarah Masuk dan Berkembangnya Islam di Indonesia (Jakarta: Bulan Bintang, 1981), h. 375.

${ }^{62}$ Teori ini disampaikan oleh HAMKA ketika ia berpidato pada acara Dies Natalis Perguruan Tinggi Agama Islam Negeri (PTAIN) ke-8 di Yogyakarta pada tahun 1958. Lihat HAMKA, Sejarah Umat Islam, h. 6.

${ }^{63}$ Hasjmy, Sejarah Masuk dan Berkembangnya Islam, h. 375.

${ }^{64}$ Sartono Kartodirjo, Sejarah Nasional Indonesia, Vol. II (Jakarta: Depdikbud, 1977), h. 73.

${ }^{65}$ G. R. Tibbets, "Early Muslim Trade in South Asia" Vol. XXX (t.t.p.: MBRAS, 1957), h. 39.
} 
tiada lain adalah gugusan pulau-pulau di Timur Jauh termasuk Kepulauan Indonesia. ${ }^{66}$ Jurnal Cina juga mengisyaratkan adanya pemukiman Arab di Cina yang penduduknya diizinkan oleh Kaisar untuk sepenuhnya menikmati kebebasan beragama. ${ }^{67}$ Pada masa itu orang-orang Islam memilih pemimpin mereka sendiri yang dinamakan imam, ${ }^{68}$ dan sejak masa itu perdagangan Indonesia mulai lancar dan maju.

Selain itu, laporan Cina yang menegaskan keputusan bangsa Arab mengirim utusan kepada Kerajaan Ho Long. Kerajaan Arab mengirim utusan ke Kerajaan Ho Long sekitar tahun 640 M, 666 M, dan 674 M. ${ }^{69}$ Sementara Kerajaan Ho Long sendiri menurut Alwi Shihab ${ }^{70}$ terletak di Jawa Timur yang bernama Kerajaan Kalingga yang terkenal dengan kemajuan dan kesejahteraan rakyat serta keadilan pemerintahannya. Sementara yang mengutus oleh orang-orang Cina dikenal dengan sebutan Tasheh sebagai nama yang mereka kenal untuk kerajaan Arab. ${ }^{71}$ Jadi, pengenalan dini kaum Muslim (Arab) terhadap Kepulauan Indonesia setaraf dengan data yang mereka ketahui mengenai Cina bahkan lebih luas. Jika demikian halnya, alasan apakah gerangan yang menjadi penghalang untuk menetapkan bahwa Islam masuk ke Indonesia pada abad pertama Hijriyah, yaitu pada masa pedagangpedagang Muslim memasuki Cina karena kedatangan orang-orang Arab membawa Islam ke Cina melalui jalur laut lama.

Dari data-data sejarah yang ada, maka jelaslah bahwa bobot historiografinya HAMKA dapat dipertanggungjawabkan secara akademis. Karena ia telah menggunakan metodologi sejarah dengan benar. Dalam penulisan buku sejarah Umat Islam ini, HAMKA telah melakukan kritik ektern untuk menilai tentang autentisitas dokumen sejarah dengan melakukan perjalanan ke tempat yang dijadikan obyek penulis sejarahnya. ${ }^{72}$ Di samping itu, HAMKA juga melakukan kritik intern terhadap sumber-sumber tersebut untuk menyakinkan bahwa dokumen itu autentik.

Sumber sejarah yang digunakan HAMKA berasal dari tiga sumber. Ketiga sumber itu diambil dari historiografi lokal seperti Hikayat Raja-raja Pasai, dan Sejarah Melayu dengan membuang hal-hal yang bercampur mitos dan legenda, hasil penelitian orang

${ }^{66}$ Yaqut al-Hamari, Mu'jam al-Buldan, Vol. III (Beirût: Dâr al-Shâdir, 1971), h. 440.

${ }^{67}$ J.C. van Leur, Indonesian Trade and Society (Den Haag: W. Van Hoeve Ltd., 1995), h. 440.

${ }^{68}$ Arnold, T.W. The Preaching of Islam: History of Propagation of the Muslim Faith (Delhi: Low Price Publications, 1995), h. 331-332.

${ }^{69}$ Grenvelt, W.P., Historical Notes on Indonesia and Malaya Compiled From Chinese Sources (t.t.p.: t.p., 1960), h. 201.

${ }^{70}$ Tentang posisi tepatnya Kerajaan Ho Long Schlegel berpendapat berada di Semenanjung Melayu dan Ferand mengatakan di Sumatera atau Borneo. Namun Alwi Shihab mengatakan di Jawa Timur. Lihat Alwi Shihab, Antara Tasawuf Suni \& Tasawuf Falsafi, h. 11.

${ }^{71}$ Kartodirjo, Sejarah Nasional Indonesia, h. 73.

${ }^{72}$ HAMKA, Sejarah Umat Islam, h. 5. 
Belanda dan orang Inggris serta pengembaraan HAMKA mengelilingi Indonesia sehingga menghasilkan sumber asli dari sejarah itu sendiri. ${ }^{73}$

Sementara historiografi A. Hasjmi tidak setinggi historiografinya HAMKA. Hal ini terjadi karena sumber sejarah yang dipergunakan oleh A. Hasjmi hanya terbatas pada bukubuku sejarah yang telah ditulis oleh sejarawan sebelumnya. Di samping itu, ia tidak melakukan kritik terhadap sumber sejarah itu. Hal ini terbukti ketika ia berpendapat bahwa kerajaan Islam pertama di Indonesia terletak di Perlak, ia tidak melakukan penelitian akan tetapi hanya bersumber dari naskah Idhar al-haqq fi Mamlakat Ferlah wal Fasi, karangan Abu Ishak Al-Makarani Al-Fasi, Tazkirat Tabâqât Jumu Sultanul Salatin karya Syaikh Syamsul Bahri Abdullah, Al-Asyi, dan Silsilah Raja-raja Perlak dan Pasai. ${ }^{74}$

Sejarawan informal berikutnya yang patut dipertimbangakan dengan karya-karya sejarahnya yang produktif dan kontroversial adalah Joesoef Sou'yb. Seorang sejarawan informal yang berasal dari Sumatera Barat yang berkarir di Sumatera Utara tepatnya di Kota Medan. Ia tidak hanya menulis buku-buku sejarah melainkan buku-buku dalam berbagai disiplin ilmu seperti bahasa, sastra, logika, ilmu kalam, filsafat, hingga komunikasi dan jurnalistik. Namun yang menjadi fokus perhatian dalam tulisan ini adalah memotret kedudukannya sebagai sejarawan informal dan melihat corak historiografinya.

Jika dibandingkan kedua sejarawan informal tersebut di atas dengan Joesoef Sou'yb, maka terdapat beberapa persamaan dan perbedaan dalam histogriorafinya. Adapun persamaan dari historiografi dari ketiga sejarawan informal tersebut menyangkut tentang pertama masuknya Islam di Indonesia. Dalam bukunya Pelaut Indonesia menemukan Benua Amerika Sebelum CH. Columbus, Sou'yb sependapat dengan teori Arabia, karena menurutnya, bahwa armada dagang pihak Islam (Arab-Parsi) sejak abad ke-7 M saling berhubungan dengan armada imperium Sriwijaya sampai abad ke-14 M. Pedagang Islam ini kemudian mendirikan perkampungan di pesisir Sumatera barat sejak tahun $674 \mathrm{M}$. Berdasarkan fakta itulah maka Islam masuk ke Indonesia lewat dakwah dan penyebaran lewat budaya seperti memperkenalkan bahasa Arab sebagai percakapan sehari-hari pada pusat kedudukan imperium Sriwijaya. ${ }^{75}$

Sementara perbedaannya adalah Sou'yb telah memperkenalkan penulisan sejarah Islam Indonesia yang bercorak global dan total. Perkembangan ini terlihat jelas terutama dalam bukunya yang berjudul Pelaut Indonesia menemukan Benua Amerika Sebelum CH. Columbus. Dalam bukunya ini Sou'yb tidak menekankan aspek historiografi pada periode dan menekankan kepada individu, namun telah memperkenalkan satu model general atau

${ }^{73}$ Ibid, h. 7.

${ }^{74}$ Hasjmi, Sejarah Masuk dan Berkembangnya Islam, h. 372.

${ }^{75}$ Joesoef Sou'yb, Pelaut Indonesia Menemukan Benua Amerika Sebelum CH. Columbus (Medan: Rainbow, t.t.), h. 47. 
total history. Dalam konteks ini, Sou'yb menempatkan sejarah Islam Indonesia dan masyarakat Islam Indonesia dalam totalitas kehidupan manusia. ${ }^{76}$

Sejarah Islam, bagi Sou'yb, hanya bisa dipahami dalam kerangka lebih luas; totalitas tidak terbatas pada Islam, sejarah masyarakat-masyarakat muslim, dan produk peradaban yang berkarakter Islam, tetapi juga dalam konteks sejarah manusia dan peradabannya secara keseluruhan. ${ }^{77}$ Pendekatan Sou'yb ini tentu mempunyai peranan yang besar dalam perkembangan historiografi Islam Modern di Indonesia. Di mana pendekatan historiografi Islam modern di Indonesia telah mengarah kepada perspektif global, yang melihat sejarah Islam di Indonesia sepanjang sejarah tidak bisa dilepaskan dari perkembangan Islam di Arabia dan kawasan-kawasan Muslim lainnya. ${ }^{78}$

Dari uraian tentang historiografi sejarawan informal di atas dapat diambil kesimpulan bahwa Joesoef Sou'yb sependapat dengan sumber sejarah kedua sejarawan di atas bahwa Islam masuk ke Indonesia datang langsung dari Makkah atau Madinah ditandai dengan adanya saling hubungan anatar armada dagang pihak Islam (Arab-Parsi) sejak abad ke-7 M dengan armada imperium Sriwijaya, ditandai dengan adanya perkampungan di pesisir Sumatera barat sejak tahun $674 \mathrm{M}$. Fakta itulah yang menunjukkan bahwa Islam masuk ke Indonesia lewat dakwah dan penyebaran budaya.

Sementara dalam persoalan konsep dan model histogriografi Sou'yb telah memperkenalkan penulisan sejarah Islam Indonesia yang bercorak global dan total. Sou'yb tidak menekankan historiografi pada periode dan menekankan kepada individu, namun telah memperkenalkan satu model general atau total history. Sejarah Islam, bagi Sou'yb, hanya bisa dipahami dalam kerangka lebih luas; totalitas tidak terbatas pada Islam, sejarah masyarakat-masyarakat muslim, dan produk peradaban yang berkarakter Islam, tetapi juga dalam konteks sejarah manusia dan peradabannya secara keseluruhan.

Setelah menguraikan corak dan bentuk historiografi 2 (dua) sejarawan informal yaitu, HAMKA dan A. Hasjmi maka aspek yang dibandingkan mengacu pada 3 (tiga) hal yaitu, (1) Dari corak historiografinya, (2) Dari bobot historiografinya (3) Dari produktivitas karya-karyanya. Antara HAMKA dan A. Hasjmi dan Joesoef Sou'yb sama-sama memiliki corak modern-konvensional artinya karena memang kedua sejarawan yang dibandingkan

\footnotetext{
${ }^{76}$ Pendekatan yang dilakukan oleh Sou'yb ini mempunyai kemiripan dengan apa yang telah dilakukan oleh Ibnu Khaldun dan Hodgson dalam pelakukan pendekatan penulisan sejarah sejarah general atau total History. Lihat Azra, Historiografi Islam Kontemporer, h. 69.

${ }^{77}$ Pendekatan Sou'yb ini juga mempunyai kemiripan dengan apa yang telah dilakukan oleh Hodgson dalam bukunya The Venture of Islam: Conscience and History in a World Civilization (Chicago: The University of Chicago, 1974).

${ }^{78}$ Pendekatan historiografi Islam modern yang mengarah pada perspektif modern ini seperti yang ditulis oleh Azra yang menulis tentang perkembangan Islam di Indonesia pada abad ke 17 dan 18 dalam kaitannya dengan kebangkitan "jaringan ulama" di Makkah dan Madinah, dan banyak bagian dunia Islam lainnya. Lihat Azra, Jaringan Ulama Timur Tengah dan Kepulauan Nusantara Abad XVII dan XVIII.
} 
adalah sama-sama hidup sezaman dan berasal dari sejarawan informal maka perbedaan antara keduanya tidak terlalu signifikan.

Berdasarkan aspek bobot historiografi yang dihasilkan HAMKA memiliki bobot yang lebih besar jika dilihat dari perspektif popularitasnya. Hal ini dapat dipahami karena HAMKA adalah tokoh nasional yang hidup di Jakarta ibu kota negara. Selain itu HAMKA juga adalah salah seorang ketua MUI Pusat yang fatwa-fatwanya dan sikap konsistensinya dalam masalah keislaman sudah diakui oleh masyarakat Indonesia secara luas. HAMKA juga pernah memimpin salah satu Ormas Islam terbesar di Indonesia yaitu Muhammadiyah pada periode tertentu dengan pertimbangan-pertimbangan di atas maka dengan sendirinya karya-karya HAMKA termasuk karya sejarahnya memiliki bobot tersendiri dalam pandangan masyarakat dalam arti bahwa kualitas karya-karya sejarahnya sudah tidak diragukan lagi. Dari aspek produktivitasnya baik HAMKA maupun A. Hasjmi dibandingkan dengan Joesoef Sou'yb maka jika melihat dari karya-karya yang dihasilkan serta dari aspek keragaman hasil karyanya maka Joesoef Sou'yb lebih menonjol dibandingkan dengan HAMKA dan A. Hasjmi.

Pemilihan tiga sejarawan informal pada artikel ini dimaksudkan agar lebih fokus pada tema yang dibahas dan kepentingan komparasi yang setara dengan latar belakang dan karya-karya mereka. Namun, tidak menutup peluang untuk menyinggung secara sepintas sejumlah nama sejarawan informal lain di luar HAMKA, A. Hasjmi dan Joesoef Sou'yb. Mereka adalah Ramadhan KH. dan Rosihan Anwar yang telah mendapatkan status anggota kehormatan dalam masyarakat sejarawan Indonesia, padahal mereka lebih dikenal selama ini sebagai seorang jurnalis.

Demikian pula Rusli Amran dari Sumatera Barat telah menghasilkan karya monumental yang berjudul Sekitar Palakat Panjang. Dibekali dengan pengalaman dan latar belakang yang hampir sama, seorang sejarawan informal asal Sumatera Timur, kini Sumatera Utara, yaitu Teuku Luckman Sinar. Ia adalah keturunan kerabat Kesultanan Serdang dikenal sedemikian banyak menghasilkan karya-karya sejarah terutama di lingkaran istana Kesultanan Serdang pada masa kolonial.

Tentu tidak kalah penting menyebut nama Muhammad Said, tokoh pejuang revolusi, seorang jurnalis, dan praktisi politik pada era Orde Lama. Ia masih dapat melahirkan karya yang patut diapresiasi sebagai bentuk kontribusi anak bangsa dengan melakukan penelitian dan observasi yang mendalam sehingga menghasilkan sebuah karya yang berjudul Atjeh Sepanjang Abad. Dari data-data di atas semakin memperkuat argumentasi bahwa

penulisan dan penelitian sejarah bukan hanya milik sejarawan akademik-formal tetapi juga absah dilakukan oleh para sejarawan informal.

\section{Penutup}

Menilai suatu hasil karya khususnya karya sejarah seharusnya diletakkan dalam 